\title{
Molecular Docking used as an advanced tool to determine novel compounds on emerging infectious diseases: A systematic review
}

\author{
K Gouthami \\ REVA University \\ V Veeraraghavan \\ REVA University
}

Ganesh Dattatraya Saratale

Dongguk University - Seoul Campus: Dongguk University

Abbas Rahdar

University of Zabol

Muhammad Bilal

Huaiyin Institute of Technology

\section{Anshuman Shah}

ICAR-National Institute for Plant Biotechnology

\section{Vandna Rai}

ICAR-National Institute for Plant Biotechnology

\section{Satish Kumar Murari}

REVA University

\section{Anyi Hu}

Institute of Urban Environment Chinese Academy of Sciences

\section{Sanjay Kalia}

Ministry of Science and Technology

Sikandar Mulla ( $\nabla$ sikandar.mulla@gmail.com )

REVA University https://orcid.org/0000-0002-3435-6457

\section{Research Article}

Keywords: Emerging infectious diseases (EIDs), Molecular docking, H1N1, HIV, Coronavirus, CYP3A4 isoenzyme, S2 (Spike protein), N1 protein

Posted Date: July 21st, 2021

DOI: https://doi.org/10.21203/rs.3.rs-319858/v1

License: (c) (1) This work is licensed under a Creative Commons Attribution 4.0 International License. Read Full License 
Version of Record: A version of this preprint was published at Progress in Biophysics and Molecular Biology on October 12th, 0022. See the published version at https://doi.org/10.1016/j.pbiomolbio.2022.10.001. 


\section{Abstract}

Emerging infectious diseases (EIDs) are among the major problems impacted on global economics and healthful living. EIDs have long been perceive as a predominant conclusion of host-pathogen adaptation. Hence, in this analysis, influence by the appearance of major factors that impact emerging infectious diseases and explicate some extensive EIDs like HIV/AIDs, H1N1 and Coronavirus. A wealth of new trends, especially in applied science is fetching progressively for the fast molecular recognizable proof of microorganisms and the more precise checking of infectious disease movement. Atomic docking is one of the prominent computational tools, involving in construction put together medication disclosure with respect to EIDs to evaluate the limiting affinities between little particles and macromolecule that can further, used as a target of HIV/AIDs, H1N1, and coronavirus. Molecular approach of influenza neuraminidase, HIV-1 protease and Spike protein of corona virus result shows Zanamivir, Nelfinavir, Saquinavir, Erythromycin and Spiramycin are favourable interaction against the selected target proteins. These novel drug compounds approved in vivo studies with reaffirm results, it is clear that the computational methods (mainly molecular docking) are found to be an effective technique for drug discovery.

\section{Introduction}

In current condition, due to various region several infectious diseases have arisen as a critical problem across the globe and few of them named as emerging infectious diseases (EIDs), for example Corona Virus (COVID-19). EIDs, generally, refers to transmissible (pandemic) diseases and exhibit with highly drug resistance properties. The spreading potential of EIDs has been enlarging rapidly and (B) Formerly appraise non-infectious diseases are recognizing contagious as a result of the new etiological discovery (Townsend et al, 2020). (C) Moreover, new infectious diseases are sustaining by various impenetrable cognition, such as the progress of pathogens (Townsend et al, 2020). Due to their unreliability and frequent genome mutability, EIDs results in huge mortality. It also results in substantial impacts on social solidity and economic evolution as people are unable to react right away and take certain preventive or control measures (Fig. 1) (Cunningham et al, 2017). Therefore, EIDs accelerate as a critical enhancer, leading to a great common health problem worldwide. EIDs are categorized as infectious agent that have lately take shape inside a populace or those whose event or geographic reach is quickly expanding. Probably, this cause takes steps to increment sooner rather than later (Cunningham et al, 2017). Emerging infections can be brought about by previously undiscovered or obscure irresistible agents, known factors that have open out to new geographic circumstance or new communities, formerly familiar agents from these roles in particular diseases have previously gone anonymous. In 2007, the WHO alert and revealed that infectious diseases are arising at a recruit that has not been previously (Cunningham et al, 2017). Since 1970s, around 40 irresistible diseases have been found, including serious acute respiratory condition (SARS), avian influenza, pig influenza, human resistant insufficiency infection/AIDS (HIV/AIDS), and most as of late, another deadly infection spread at pandemic level as (COVID-19) (Table 1) (Massinissa et al, 2018).

Infectious diseases have declined as a cause of all over the world. Over the previous few decades, proved vaccination, antibiotics and sanitation, participate as a major player to limit the spreading potential of such infectious agent. However, in the previous twenty years the event of emerging infectious diseases has increased (Table 2) (Massinissa et al. 2018). The finding of disease-causing pathogens including, virus, bacteria protozoa, fungi, helminths, and prions are identified or conformed as dangerous pathogen (Bloom et al. 2017). A centre for disease control program starts in 1995 , discovered about a hundred sufferers, with life tormenting sicknesses, which were contemplated to be of an irresistible reason, yet couldn't be connected to a known microorganism (Bloom et al. 2017). The alliance of pathogens with the disease can be a composite and controversial process, in some instances requiring decades or even centuries to attain total sway on the etiological agents (van Doorn 2014). Vectors and microbes float in the developmental, 
respiratory or blood stream. On the other hand, bacteria can be replicated by every 30 minutes and therefore, can release their toxin very quickly to hijack the host immune system. This may lead to adverse effect on host homeostasis. More emerging diseases come about when infectious agents in animals proceed to humans as zoonosis (van Doorn 2014). As the anthropoid population enlarges in number and into the latest geographical regions, the prospect that humans will come into direct contact with animal species that are possible hosts of an infectious agent increases (van Doorn 2014). The exchange aspect of irresistible infections in the direction of the last two decades has surprised the medical professionals and the public. Emerging microbes that cause current diseases (e.g, SARS-COV), newly accept microbial agents of known diseases (e.g, human meta-pneumovirus), and continuously develop pathogens (e.g., swine flu) all contribute to this seismic shift (van Doorn 2014). In spite of the advancement of drugs for treating and managing HIV/AIDS, H1N1 and Covid-19, these illnesses are continuing to epidemic diverse populations worldwide with significant associated-mortalities (Sarafis et al. 2010; Grace et al. 2011). There is need for experimental drug discovery approach that alter from the current Pharma R\&D strategies. To overcome these problems molecular docking technique utilized as a major tool to discover novel drugs for EIDs. Evolution of new novel drugs can value anywhere in the range of 400 million to 2 billion dollars, with testing and synthesis. AIDS, flu, and other illness related infections to the current 2019-nCoV have been functioning dense to create antiviral medications focusing on them. In general, infections don't have their own metabolic system and cellular structure, but once they enter into the host cells and immediately start controlling biosynthesis of host cell and in this manner starts required machinery production for proliferation and replication. Hence, the distinctive proliferation and structure of individual virus poses a characteristic test for drug improvement. In this way, it is hard to track down compounds that are targets just infection without influencing the typical capacity of host cells (Sarafis et al. 2010; Grace et al. 2011). At present situations, for EIDs, the main way to look on few anti-viral and anti-inflammatory drugs which works against viruses and thereby inhibit viral replication. At the present a lot of the devices utilized for infection reproduction come from human being cells, for example, ribosomes, and the bestow antiviral medications will moreover show exceptional outcomes to the individual body. Consequently, the acknowledgment of medications needs the commencement of a multi-scale model to screen out medications that can hinder viral replication while cut down the harm to the human body (Grace et al. 2011; Mehand et al. 2018).

With the fast advancement of both program and calculations, drug screening and configuration have acquired a lot of thought from various computational methods which incredibly lessen the expense and season of medication improvement. In common, computational methodology can help to uncover the vital qualities from a monstrous measure of genomic information and along these lines, give conceivable objective proteins to drug screening and plan (Grace et al. 2011; Mehand et al. 2018). Bimolecular reflection with dynamic models allows for the examinations of both underlying and thermodynamic highlights of target proteins at various levels which are helpful for distinguishing drug restricting locales and clarifying medication activity instruments. Virtual screening at that point explores compound information centre to gives potential drug contender to construct drug restricting locales on target macromolecules. With considerably decrease quantity of viable drug competitors, in-vitro cell investigation can further estimate the adequacy of these molecules. The best compounds after molecular docking uses the cytotoxicity examines are expanding to investigate the constraint of specific medication compounds to destroy the solid cells of a living being. Cytotoxic mixtures can incite modified cell passing (referenced to as apoptosis). During the clinical and nonclinical research periods of medication disclosure and evolution, cytotoxicity assays estimate the safety profile of the medication candidate. The method demonstrates important in distinguishing off-target impacts of certain medication compounds on the individual body. For drug intensifies created for therapy, cytotoxicity measures are basic in an assortment of testing movement (Grace et al. 2011; Mehand et al. 2018). After cytotoxicity assay further step of clinical trials needs in vivo studies are critical in drug progress for evaluating a drug's pharmacokinetic and pharmacodynamics characteristics. In vivo studies ability to provides using of distribution, metabolism, quantitative 
results of absorption and excretion in animal and human models. The use of in vivo studies foregoing to a drug becoming commercially approachable is critical for understanding the characteristics and outcome of a drug within a living organism (Grace et al. 2011; Mehand et al. 2018).

\section{Emerging Infectious Diseases}

At present, more than 40 EIDs have been identified worldwide, and over 30 kinds of EIDs have been reported in China (Tang et al. 2018). Incidence of EIDs is rapidly increasing over the geographic level. In addition, National institutes of allergy and infectious diseases categorized the pathogens as A, B and C level based on their method of activity or extent of severity. Pathogens group comprise Bio-defense Research and Additional Emerging Infectious. Infectious diseases classify-A, pathogens are that microorganisms, present on one of the risks to public health, because they can easily transfer from person to person. This results in huge temporality charge and viable for major public health impact, might cause public panic and social disturbance and needs special steps for public health preparation (Tang et al. 2018; Jin et al. 2016). Classify-B, pathogens are the second great priority organisms/biological factors. They are some pathogens easy to spread, bring about moderate horribleness charges and less mortality charges, need specific upgrades for analytic volume, and improved illness perceptions. Classify-C pathogens are the third huge category, and include emerging pathogens that could be manipulated for mass spreading in the future, since it causes the microorganism accessibility and dissemination, will give the potential for raised horribleness and mortality charges, and great health impact (Tang et al. 2018).

\subsection{Factors contributing to Emerging infectious diseases}

There are numerous factors engaged with the development of new emerging infectious diseases. Natural processes such as the evolution of pathogens after some time, yet many are a consequence of human conduct and practices. Consider how the cooperation between the human population and our current environment has changed, particularly in the only remaining century. Elements that have added to these progressions are population development, relocation from rustic regions to urban areas, worldwide air travel, destitution, wars, and damaging natural changes because of financial turn of events and land use. Improvement of pathogenic infectious agents due to evolution like microbial changing and convert, obstruction against the medication, and opposition of vectors to pesticides (Poorolajal et al. 2020). Some of other factors like anthropogenic activities trade (possessing new locale), Human direct (sexual and drug use), human powerlessness to disease (Immunosuppression), destitution and social disparity, and changes in way of life that advance unfortunate and danger inclined conduct configuration impact food propensities and sexual practices (Poorolajal et al. 2020).

Moreover, climate has an important environmental influence on ecosystem. Substitute climate influence ecosystems in a diversity of ways. For occurrence, warming may power species to meander to higher scopes or higher heights, where temperatures are more important to their endurance (Jin et al. 2020). Its influence on agricultural area and food animal production systems on horticultural areas engaged with zoonotic flare-ups regularly endure huge financial effects that are undervalued. Environmental sanitation classified by inappropriate removal of strong and fluid waste, risky water supply, poor clean practices and overfull day to day environments all provide for the development of disease, worldwide travel and business, breakdown of general wellbeing measure (war, turmoil, congestion) and decay in reconnaissance frameworks (absence of political will) (Fig. 1) (Jin et al. 2020; Venkatramanan et al. 2018). (A) Host convert (host novelty), splinting of pathogen persistence thresholds, transmission elaboration and genetic interchange. (B) optimal climatic conditions: precipitation and temperature are the most dominant, while sea level upgrading, wind, and day light extent are also important (Jin et al. 2020; Venkatramanan et al. 2018). (C) infectious diseases are majorly causing the vector-born, Air-born, Food-born and Water-borne pathogens include the enteric virus's rotavirus

Page 5/24 
and norovirus and the bacteria Campylobacter spp. and Vibrio cholera, which collectively cause millions of deaths annually, particularly among infants.

\subsection{Transmission of Infectious Agent}

\subsubsection{Animals to Humans}

Irresistible illnesses emerge upon contact with an irresistible specialist. Five significant irresistible specialists have been perceived, specifically, microbes, infections, growths, protozoa, and helminths (Nii-Trebi et al. 2017). Different components can be distinguished that set out open doors for irresistible specialists to attack human hosts. While hosts favor transference to different species including wild creatures, homegrown creatures, and people, changes in powerless host conduct because of populace thickness and biodiversity favor supported microorganism spread. Epidemics in pandemic Human commitment in exercises that meddle with natural and ecological conditions proceeds, in this way expanding the danger of contact with new microbes. Emerging infections appear from domestic to wild animals (Kilian et al. 2016; Venkatramanan et al. 2018). EIDs in people related with Pigs, Chickens and Geese. Creature disengagement looking for food after deforestation/environmental change (Lassa fever), human on selves' infiltrate/adjust disrupted locales come nearer to creature repositories/vectors (Yellow fever, Malaria).

\subsubsection{Environmental \& Climate factor}

Deforestation powers creatures to go into prompt human contact-extended opportunities for specialist to breaking species boundary between animals\& individuals, El Nino (This alludes to times when waters of the tropical eastern Pacific are colder than ordinary and trade winds blow more solidly than anticipated) activate cataclysmic events and connected episodes of irresistible illnesses (Cholera, Malaria) and a worldwide temperature alteration spread of Malaria, Dengue, Leishmaniasis, Filariasis (Kilian et al. 2016; Venkatramanan et al. 2018).

\subsubsection{Impacts on Poverty, Neglect \&Weakening of Health Infrastructure}

Health, poverty and livelihoods are the three main considerations that influence provincial population in developing countries, the determinants of poverty, health and livelihoods are shown the significant idea of arising irresistible illnesses (Smith et al. 2019). Pandemic readiness anyway stays a significant worldwide test. An unpredictable number of components identifying with human conduct and exercises, microorganism advancement, destitution, and changes in the climate just as unique human communications with creatures have been found to add to irresistible sickness development and transmission. Emerging irresistible illnesses are a genuine general wellbeing danger, and irresistible sickness episodes can have genuine social, political, and financial impacts. The population huge repository and source of continue with transmission, neediness un healthiness severe irresistible infection cycle absence of help, poor prioritization of wellbeing reserves, misplaced in remedial as opposed to inhibitory foundation, Inability to create satisfactory health conveyance frameworks.

\subsubsection{Unconstrained Population \& Urbanization Displacement}

Extension of slowly populated urban areas faulty lodging, less sterilization, risky water, stuffing, inside air contamination, difficulty of refugees \& displaced persons, (Eisinger et al. 2018; Marcus et al. 2017) diarrhoeal \&Intestinal parasitic illnesses, ARI Lyme sickness (B. burgdorferi)- trade in nature, rural relocation of populace, expand deer populaces.

\subsubsection{Human Behaviour}

Page 6/24 
Human conduct assumes a significant part in the spread of emerging arising irresistible illnesses, and understanding the effect of direct changes on pandemics can be basic to improving control endeavours. Notwithstanding, how the elements of individual direct changes imply for the progression of arising irresistible infection is a key general medical problem (Smith et al. 2019). Hazardous sexual practices (HIV, Gonorrhea, Syphilis), changes in horticultural and food creation designs food-borne irresistible specialists, for example, E. coli, expanded worldwide travel (Influenza) and open-air action (Eisinger et al. 2018; Marcus et al. 2017).

\subsubsection{Antimicrobial Drug Resistance Microorganisms}

Risk factors for rise and spread of antimicrobial drug-resistance microbes and other arising sicknesses in nonindustrial nations is expected to configuration suitable intercessions (Nii-Trebi et al. 2016). The data suggested that the antimicrobial drug resistance microorganisms are having key role in spreading EIDs, for example in India, metallo$\beta$-lactamase has increased more than eight folds from $3 \%$ to approximately $25 \%$ within three years (Asokan and Kasimanickam, 2013). Exploration should address creature farming and human medication use, social and financial effects on recommending practices and prescription practices, customary convictions and neighbourhood societies, and ecological elements that advance transmission of irresistible illnesses and medication safe microorganisms. Consequences include prolonged hospital admissions, higher death rates from infection. To limit the drastic effect of antimicrobial drugs on human body, every time antibiotics should not use for normal diseases. If needed, drug must be used target specific (Kilian et al. 2016).

\section{Most Effective Eids On Human Beings Are Hiv/aids, H1n1 And Corona Virus}

\subsection{HIV/AID}

Acquired immunodeficiency syndromes is a group of side effects because of crucial irritations and malignancies coming about because of specific injury to safe framework achieve by human immunodeficiency infection (HIV) (Rueda et al. 2016). In 1986, the International Committee on infection classification settled on the nonexclusive name of the causative infection as the human immunodeficiency infection (HIV). Approximately 25 million of human beings have died from this disorder. It is an assumption that human beings were first contaminated with HIV through near contact with chimpanzees, perhaps through bush meat hunting, in confined regions of Africa (Rueda et al. 2016; Becerra et al. 2016). It is probable that HIV then open out from rural regions into cities and then internationally through air travel (Becerra et al. 2016). Further parts in human conduct, for example, intravenous medication use, sexual correspondence, and move of blood results before the sickness was acknowledge, helped the quick and extensive spread of HIV (Cimarelli et al. 2016).

Acquired immunodeficiency syndromes is caused by human immunodeficiency infection inalienably the infection has ordered two sorts HIV-1 worldwide and HIV-2 forceful sluggish and confined for the most part to western Africa. Retroviruses are a particular class of viruses which belongs the HIV (Cimarelli et al. 2016; Fauci et al. 2019). Inside this class, HIV is getting comfortable the region of lentiviruses. Other lentiviruses include SIV, FIV, Visna and CAEV, which cause issues in monkeys, felines, sheep and goats. All infections (with the exception of retroviruses) contain DNA. In this way, retroviruses are the exemption, on the grounds that their qualities are made out of RNA (Ribonucleic Acid) (Fauci et al. 2019). Be that as it may, RNA has a fundamentally the same as design to DNA with little contrasts. HIV has just nine genes compared to bacteria which are having more than 500 genes. Out of nine HIV genes, three of them (gag, pol and env) carry required essential information to create constructional proteins for new virus components (Fauci et al. 2019; Zhan et al. 2016). The rest of six qualities (tat, fire up, nef, vif, vpr and vpu) codes for proteins that control the limit of HIV to taint a host cell, develop new duplicates infection as well as cause sickness (Zhan et al. 
2016). HIV particles encompassed themselves with a layer of greasy substance known as the viral covering. This covering gives out a significant part of little spikes around 72 in number. These spikes are made of knobs and handles which made of biomolecule proteins, gp120 and gp41, separately. The viral covering down a layer called the network, which is worked from the protein p17(Matrix proteins) (Jayakanthan et al. 2010; Zhan et al. 2016). Beneath the network is one more layer of proteins P24 discovered viral center (or capsid) and is typically slug formed. Inside the center has three proteins needs for HIV replication called Reverse Transcriptase Integrase and Protease likewise held inside the centre is HIV's hereditary material, which fuse of two indistinguishable duplicates of single abandoned RNA (Jayakanthan et al. 2010; Minardi da Cruz et al. 2013). Besides, it was seen that RNA segment conveys roughly 9750 nucleotides. At the point when HIV taints a cell, it first appends to and wires with the host cell. By then the viral RNA is changed over into DNA and the disease uses the host cell's mechanical assembly to repeat itself during a cycle called invert record. The new copies of HIV by then leave the host cell and continue ahead to taint different cells. HIV can't reproduce in isolation, so to make new copies of itself, it ought to taint cells of the human resistant framework, called CD4 cells. CD4 cells are white platelets that expect a focal part in reacting to infections in the body (Minardi da Cruz et al. 2013; Pornillos et al. 2002). After some time, CD4 cells are killed by HIV and the body's ability to see and battle a couple of sorts of contamination starts to diminish. On the off chance that HIV isn't constrained by therapy, the inadequacy of CD4 cells prompts the progression of certified disorders, or adroit illnesses. In people with normal CD4 cell levels, these contaminations would be seen and cleared by the invulnerable framework. Passage to the cell begins

through collaboration of the trimeric envelope baffling and both CD4 and a chemokine receptor on the host cell on the cell surface. The HIV coat protein, gp120, binds to integrin $a 4 \beta 7$, inciting LFA-1 (the central integrin related with the establishment of frameworks known as "virological synapses") which urge powerful cell-to-cell spreading of HIV-1. After HIV has focus to the objective cell, the HIV RNA and various proteins (tallying reverse integrase, ribonuclease, transcriptase and protease) are injected into the cell (Najla et al. 2016). Since HIV association is essential for the HIV replication cycle, understanding the specific instruments through which HIV association happens has recommendations for expected medicines of HIV.

\subsection{H1N1}

Flu spreads around the globe in occasional pandemics. Resulting in $10 \%-20 \%$ of the populations were affected by the seasonal epidemics influenza and about 2.5 to 5.0 lakhs yearly deaths. Influenza is brought about by transformations in the viral genome because of a mistake prone RNA polymerase (Lewis et al. 2016). In the $20^{\text {th }}$ century, three influenza pandemic arises through antigenic shift, resulting in aspect of new strain of the infection in individual. The new strain was found more dangerous and was not related to previously infecting strain to human seasonal influenza viruses and kills a huge number of individuals. New flu virus strains show up while existing seasonal infection transmitted from birds and mammals to human (Lewis et al. 2016; Hung et al. 2018 Flu is an overall plague and it causes significant dismalness and mortality. There are three sorts of flu infections found in the climate for example A, $B$ and $C$. In that flu B infection contaminates just people and Influenza An infection taints a wide scope of avian and mammalian hosts (Hung et al. 2018). Influenza C virus sometimes it causing both local epidemics and severe illness. These viruses are belonging to paramyxovirus family and it also related to human parainfluenza virus. Influenza viruses' reason for respiratory contaminations in kids, for example, croup and can likewise cause an infection like flu in grown-ups (Henritzi et al. 2019) Moreover, it was observed that an influenza A virus is common cause of respiratory infection all over the world. Influenza viruses contains RNA as a genetic material with segmented genome; which contain of 8-ve sense, single stranded segments (vRNA) (Hung et al. 2018; Henritzi et al. 2019). These segments are code for eleven proteins in which two are surface glycoproteins (hemagglutinin (H protein) and neuraminidase $(\mathrm{N}$ protein)). Hemagglutinin is a glycoprotein that makes red platelets agglutinate and neuraminidase is a compound that divides the glycosidic obligations of the monosaccharide, neuraminic corrosive (Monamele et al. 2018). Diverse flu 
infections encode for various $\mathrm{H}$ and $\mathrm{N}$ proteins and these variations are named by the species (have) in which the strain is endemic or to which it is adjusted. A portion of the variations are named utilizing their traditional term like Human influenza, Bird influenza, Swine flu, Canine flu, Equine flu and so forth. (Monamele et al. 2018). There are $16 \mathrm{H}$ $(\mathrm{H} 1-\mathrm{H} 16)$ and $9 \mathrm{~N}(\mathrm{~N} 1-\mathrm{N} 9)$ subtypes of flu infection, all these distinctive flu infections encode for various hemagglutinin and neuraminidase proteins. These surface proteins are key harmfulness determinants and inspire the fundamental host resistant reaction. In life cycle of influenza virus, M2 protein, hemagglutinin (HA), and catalyst sialidase (NA) are the three surface proteins of flu an infection. Flu infection is an encompassed infection, it binds to human, flu infections (a2-6 sialic acids) and to avian flu infections (a 2-3 sialic acids) through HA surface glycoproteins. The enzymatic action of breaking a-ketosidic linkages by Neuraminidase (NA) drives the disease to go into cell by endocytosis, this will occur through receptor-intervened instrument. After the infection section, it binds with endosomal layer. Because of diminishing of $\mathrm{pH}$ for up to 6, endosome changes into lysosome (Anderson et al. 2016). The HA particle unfurls coming about into openness of shrouded hydrophobic chain of HA and known as combination peptide. At last, the viral nucleocapsid discharges into cytosol of the host cell and afterward protein union happens in cytoplasm. This infection discharges through growing. sialidase elutes infection from cell surface and infection would now be able to contaminate different cells.

\subsection{Corona virus}

In December -2019, a novel corona virus (SARS-CoV-2) appeared in the city of Wuhan, China and give raise to severe morbidity and mortality ( $\mathrm{Li}$ et al. 2020). Covid (CoV) are an enormous group of infections that achieve sickness stretches out from the typical virus to extra extreme illnesses, for example, Middle East Respiratory Syndrome (MERSCoV) and Severe Acute Respiratory Syndrome (SARS-CoV) (Li et al. 2020; Schoeman et al. 2019). An epic Covid (CoV) is another strain for human beings which has not identified earlier. Moreover, these are zoonotic, implies, they are conveying among creatures and individuals (Schoeman et al. 2019). Complete investigation sets up that SARS-CoV was sent from civet cats to individuals and MERS-CoV from dromedary camels to individuals. then, there are known Corona virus which are changing in creatures that have not yet tainted people (Schoeman et al. 2019). SARS-CoV-2 mentions to severe acute respiratory syndrome coronavirus 2 which was reported by ICTV (International Committee on Taxonomy of Viruses) as name of the new virus on $11^{\text {th }}$ February 2020 (Ji et al. 2020; Al et al. 2019). The name was designated due to its sequence matches with corona virus which is responsible to SARS outbreak in the year 2003 (Al et al., 2019). While related, the two viruses are different. Present situation HCoVs (Human Corona Virus) identified as most expeditiously evolving virus outstanding genomic recombination and nucleotide substitution sequence. Till date as per WHO report 6 known HCoVs genes have been identified such as HCoV-OC43, HCoV-229E, HCoV-NL63, HCoVHKU1, SARS-CoV (Severe Acute Respiratory Syndrome Corona Virus), MERS-CoV (Middle East Respiratory Syndrome Corona infection). Clinical administration include brief execution of proposed disease anticipation and control quantifies and considered administration of problems, including advanced organ support if indicated (Sohrabi et al. 2020). Corticosteroids should be kept away from, because of the possible for prolonging viral replication as noticed in MERS-CoV patients, unless recommended for further causes. For example, for a COPD aggravation or for septic shock per get through Sepsis recommendation (Sohrabi et al. 2020; Taiaroa et al. 2020). Coronavirus are enormous, wrapped, in addition to abandoned RNA infections. The virion incorporates the ribonucleoprotein (RNP) center, comprising of a genomic RNA that is the biggest among all RNA infections, in complex with the nucleocapsid (N) protein. The RNP is encircled by a lipidic envelope (Boni et al. 2020). Three viral proteins are moored in the envelope of all CoVs: Membrane (M) protein, Envelope (E) protein Spike (S) protein, the viral surface proteins can be found in downstream compartments of the secretory pathway when communicated by the infection or alone: M confines overwhelmingly in the Golgi apparatus. $\mathrm{M}$ can also interact with RNA that carries the genomic packaging signal (Cascella et al. 2020; Ahmad et al. 2020). It is protein with three transmembrane spaces and is thought to give the 
virion its shape. $\mathrm{M}$ can also interconnect with RNA that transport the genomic wrapping signal. It is protein with three transmembrane spaces and is thought to permit the virion its shape (Awaidy et al. 2020). The N protein is the lone protein constituent of the helically symmetric nucleocapsid, which is situated in the inside of the virion. Covid $\mathrm{N}$ proteins are to a great extent essential phosphoprotein (Liu et al. 2020; Zhu et al. 2019). It is made out of two separate spaces, a N-terminal area (NTD) and a C-terminal area (CTD), both fit for restricting RNA in vitro. Viral genome ties the $\mathrm{N}$ protein in a dots on-a-string type compliance (Morens et al. 2020).

\section{Molecular Docking Tools Importance On Emerging Infectious Disease}

Over the past decade, the global effort to identify and formulation of infectious agents, enlarge preventive estimations and treatments for many of the world's most threatening pathogens has resulted in considerable progress in EIDs and potential bioterror agents (Xie et al. 2018). Numerous beginning research determinations have been interpreting into antiviral and antimicrobial compounds, novel diagnostics, and vaccines, often with remarkable speed. Large-scale of individual drug compounds are identified for EIDs. Present days, most of the researchers are using the computational instruments that can be utilized in medication disclosure, Molecular docking is one among the computational tools. It is a form of structure-based drug discovery tool that qualifies the binding affinities between little particles and macromolecule which can be used as a target (Xie et al. 2018). Sub-atomic docking studies can be performed utilizing realized ligands like normally happening particles or potentially known medications as well as novel ligands. Virtual screening dependent on perceived novel ligands with sub-atomic docking gives a particularly useful strategy for drug disclosure, since, particles can be starting to have high restricting liking to an unmistakable site. Molecular Docking contemplates are regularly affirming to use further computational strategy like atomic unique reproduction (Phillips et al. 2018). The most successful applicants from computational preliminaries can be tried in vitro or in vivo, and finally progress to clinical preliminaries. EIDs are pandemic and pestilence around the drove monstrous measures of cash into research that searches for approaches to help treat and forestall this infection (Phillips et al. 2018). Since, bringing a medication into market can require quite a while and costs, colossal measures of cash, it is absolutely critical of specialists to utilize a savvy approach to locate these new therapeutics (Pagadala et al. 2017). Computational techniques have been slowly becoming regular place in medication configuration research. These means have been either affirming acknowledged examination, finding new mixtures, restricting destinations or conformance, and even allows for the repurposing of the medication to treat different ailments (Pagadala et al. 2017). Techniques for example, molecular dynamics and docking are decline analysts' significant time. These procedures are likewise offering examination to make exact and explicit forecasts of what's going on at the sub-atomic level (Pagadala et al. 2017; Ferreira et al. 2015). Durational computational medication plan strategies are presently here close to supplanting in vitro and in vivo testing, in silico testing is getting continuously acknowledged for exploration or move as a set up point for in vitro testing (Pagadala et al. 2017; Ferreira et al. 2015). This segment will present how analysts utilized computational techniques to help distinguish drugs for EIDs (Fig.2). Which are shown in few ways and are as follows; (A) Target proteins to read different structures, conformations and docking sites. (B) Ligand to

upload in format of Mol, sdf, pdb or smiles (Xie et al. 2018). (C) System prediction for to generate docking parameters, to generate optimize the 3D structures of the ligands. (D) Molecular docking structure based virtual screening to predict the binding site detection. (E) Auto dock prediction shows the docking scores and coordinate files related to protein-ligand interaction (Ferreira et al. 2015).

\section{Molecular Docking Approach To Determine Novel Compounds On The Emerging Infectious Diseases}

5.1 Molecular docking study of HIV/AIDS

Page 10/24 
AIDS obtain in anthropoid by the retrovirus HIV. HIV impact essential associate T cells in the human safe structure independently CD4 T-cells. HIV is spreading as single-deserted, positive-sense, enveloped RNA disease (Jacobson et al. 2020). Human immunodeficiency infection 1 (HIV-1) is one of the prevail expectation for clinical examination causes AIDS in human. This RNA infection reproduces inside the host cell by absorb its hereditary material with the host cell genome. Certain investigates are procedures worldwide to balance the movement of this infection for restoring HIV-1 tainted patients (Valdiserri et al. 2019). analysts are for the most part focusing on the HIV-1 converse transcriptase, HIV-1 protease and HIV-1 integrase to obstruct the antecedent structure and ought to be severed to change into develop, completely practical proteins to taint the cells (Jacobson et al. 2019; Valdiserri et al. 2019). Proteolytic cleavage of the viral polyprotein antecedents is required HIV-1 protease to change into the individual useful proteins. Inactivation of HIV-1 protease by explicit synthetic mixtures should deliver the infection non-irresistible. The mixtures like ritonavir (RTV), amprenavir (APV), tipranavir (TPV), indinavir (IDV), saquinavir (SQV), nelfinavir (NFV), lopinavir (LPV), fosamprenavir (FOS-APV), darunavir and atazanavir (ATV) are the US-FDA affirmed drugs accessible for HIV-1 protease hindrance (Eisinger et al. 2019). In human CYP450 proteins, CYP1A2, CYP2C9, CYP2C19, CYP2D6, and CYP3A4 are the significant medication using isoforms, which assumes a significant part in the oxidative digestion of $90 \%$ medications in the current clinical use. Of these isoforms, CYP3A4 is engaged with the digestion of over half medications and another xenobiotic. The nuclear directions of without ligand human microsomal cytochrome P450 3A4 (CYP3A4) was recovered from Protein Data Bank (PDB ID: 1TQN). This construction was controlled by X-beam crystallography to $2.05 \mathrm{~A}^{\circ}$ goals. In this work, atomic docking examines were performed to investigate conceivable restricting methods of HIV-1 protease drugs into CYP3A4 (Kazhila et al. 2019).

AutoDock 4.0 programming was utilized to dock protease drugs into CYP3A4. The particular restricting example of amino corrosive deposits taking part in metabolic freedom was distinguished sensibly and approved by site of the response and collaboration energies of the docked edifices (Zhu et al. 2019). The docking results display that Arg212 offered prevail allowance in hydrogen bond advancement, which demonstrate in the medication collaborations and Arg105, Glu374, Ser119, Arg106, Ala370, and Arg372 additionally partook in hydrogen holding with nearly higher recurrence (Table 3). The normal restricting method of every HIV-1 protease drugs was set up to have quality relationship with the exploratory information of inhibitory exercises (Sk et al. 2020; Cheng et al. 2018). Docking results recommended that HIV-1 protease drugs TPV, NFV, LPV, and ATV are contrasted in their limiting agreement into CYP3A4, while RTV, APV, IDV, SQV, FOS-APV, and darunavir share a similar restricting mode. Just as, the recognized supported awaiting methods of CYP3A4 into medications will be helpful for the improvement of new HIV-1 protease drugs and furthermore gives significant bits of knowledge into the digestion of medications (Tarasova et al. 2018). After clinical preliminaries the HIV protease inhibitors and their possible off-target atoms, we could get hints for improving the sub-atomic selectivity of the inhibitors, to give assistance in the plan of new mixtures with upgraded bioavailability and decreased results. Exactly when a protease inhibitor blend of HIV-1 protease drugs NFV, LPV, TPV and ATV blocks protease, HIV can't separate its proteins to make new infections. Hence, it can't duplicate, and it quits spreading. protease inhibitors can reduce HIV to imperceptible levels in the body.

\subsection{Molecular docking study of H1N1}

Swine flu Influenza A virus belongs to the viral group of orthomyxoviridae. They are RNA infections with a sectioned genome that is involved single abandoned RNA portions. These eight fragments encode eleven proteins in which two are surface glycoproteins, hemagglutinin (HA) and neuraminidase (NA) (Dammalli et al. 2014). HA ties with sialic corrosive identified on the outside of the focused-on host cell to start infection disease and sialic corrosive was pull out from infection by NA. By the far beyond two stages activities, $\mathrm{H}$ and NA improve infection salvage and the stretch out of contamination to current cells (Lai et al. 2020). By clog HA or NA could deflect infection from attacking into have cells. In one of the investigations NA was picked as medication target and was a glycoprotein that group the sort 
of flu an infection. The ligands like Stilbenoids_19, Stilbenoids_23, Stemonine, Tuberospironine, Croomine, Zanamivir, Oseltamir are used against the glycoprotein (Table 4). The ligand molecule was docked into NA modelled structure (Bennett et al. 2019). The docking postures of best compound association among this Stilbenoids_19 had the most reduced restricting energy score of $-14.0181 \mathrm{kcal} / \mathrm{mol}$ and is considerably lesser than the standard controls zanamivir that had - $3.5972 \mathrm{kcal} / \mathrm{mol}$ and oseltamivir and $-3.6546 \mathrm{kcal} / \mathrm{mol}$. Curiously, remaining mixtures were stronger than zanamivir and oseltamivir. The Stilbenoids_19 had six hydrogen bond trade with the demonstrated protein (Yasuhara et al. 2017). The build-up THR 131 had two hydrogen bond collaborations with the bond length of $0.220741 \mathrm{~nm}$ and $0.189968 \mathrm{~nm}$, individually, PHE133 had two hydrogen bond cooperation's with the bond length of $0.236485 \mathrm{~nm}$ and $0.185986 \mathrm{~nm}$, separately and CYS161 additionally had two hydrogen security communications with the investigation has set out on to plan another sub-atomic lead by structure-based docking system utilizing NA as the objective. PC supported medication planning and sub-atomic docking examination are exceptionally powerful in making and investigating new competitor drug particles. The anticipated protein homology model had $88.2 \%$ and $10.3 \%$ supported and extra permitted locales, separately (Yasuhara et al. 2017). The mixtures Stilbenoids_19, stilbenoids_23, stemonine and tuberospironine were chosen as intense objective competitor drugs for H1N1. The atomic docking investigation of N1 with FDA affirmed drugs Zanamivir and Ositamvir was assessed to distinguish the comparable bioactivity. The docking result showed that Stilbenoids_19 had the most reduced restricting energy of - 14.0181 when contrasted with FDA affirmed drugs. The docking investigations of Stilbenoids_19 on the streamlined and energy limited model of NA show some significant deposits. This molecule can be utilized for structure based and pharmacophore based new medication scheming for advancement of novel helpful specialists for the interference and treatment of H1N1 (Mugosa et al. 2016). A mix of homology displaying, virtual screening and sub-atomic docking, putative novel NA inhibitors can be recognized, which can be furthermore evaluated by in vitro and in vivo biological tests.

\subsection{Molecular docking study of Corona virus}

COVID-19 is containing a single-stranded large RNA virus, enveloped and positive-sense. corona viruses contain four sub divided families -Alpha, beta, gamma, and delta (Chen et al. 2020). $a$-and $\beta$-Covid discovered to be begun from bats (Yang et al. 2014), while gamma and delta-infections started from pigs and flying creatures' Different Covid have been recognized Human Covid OC43 (HCoV-OC43), Human Covid HKU1, Human Covid NL63 (HCoVNL63), Human Covid 229E (HCoV-229E), Middle East respiratory disorder related Covid (MERS-CoV), Severe intense respiratory condition Covid (SARS-CoV) and right now Severe intense respiratory disorder Covid 2 (Gordon et al. 2020).

The S2 (Spike protein) comprises of the ectodomain district (ED), the intracellular area, and the transmembrane (TM) locale (Gordon et al., 2020). Clove-shaped S protein is a sort I TM protein. The ED district is designed up of 2 receptor restricting spaces (RBDs), the S1 subunit and the S2 trimeric tail, co related with the C-terminal (Manli et al. 2020). The association of $\mathrm{S}$ proteins gives the virion a trimeric structure, which gives it a crown-like design and the name corona virus. The role of $S$ protein has an in viral section. It has been reported that the $S$ protein activated the host immune response (Manli et al. 2020). This protein is viewed as a likely objective for a helpful medication, in light of the fact that the S1 area and host ACE2 for SARS-CoV, and dipeptidyl peptidase-4 for Middle East respiratory condition Covid, are related with have and viral layer combination mediated by the S2 section and empower the infection to convey its RNA in the host cell. Forecast of protein structure is significant in atomic docking, utilizing I-TASSER to fabricate threedimensional protein structure and utilized for homology displaying utilizing Swiss PDB Viewer (SPDBV) programming (Velavan and Meyer 2020). The Molecular techniques are applied in the current investigation are, Molecular docking, virtual screening, drug-like and ADMET expectation assists with focusing on CoV inhibitors. The outcomes were screened dependent on $\mathrm{H}$-bonds, docking score, and amino corrosive communications (He et al. 2020). The outcomes shows HIV-protease inhibitors, for example, Lopinavir (- $9.1 \mathrm{kcal} / \mathrm{mol})$, cobicistat $(-8.3 \mathrm{kcal} / \mathrm{mol})$, Darunavir ($7.4 \mathrm{kcal} / \mathrm{mol})$, and Ritonavir (- $8.0 \mathrm{kcal} / \mathrm{mol})$, calming medications, for example, Baricitinib (- 5.8kcal/mol), Ruxolitinib 
$(-6.5 \mathrm{kcal} / \mathrm{mol})$, Thalidomide (-6.5kcal/mol), anti-toxin drugs mitigating medications, for example, Ruxolitinib ($6.5 \mathrm{kcal} / \mathrm{mol})$, Baricitinib $(-5.8 \mathrm{kcal} / \mathrm{mol})$, Thalidomide $(-6.5 \mathrm{kcal} / \mathrm{mol})$, anti-infection medications, for example, Erythromycin $(-9.0 \mathrm{kcal} / \mathrm{mol})$ and Spiramycin $(-8.5 \mathrm{kcal} / \mathrm{mol})$ particles have great proclivity towards spike protein contrasted with antimalarial drugs Artemisinin $(-6.8 \mathrm{kcal} / \mathrm{mol})$, Chloroquine $(-6.2 \mathrm{kcal} / \mathrm{mol})$, Hydroxychloroquine $(-5.2 \mathrm{kcal} / \mathrm{mol})$ and have helpless partiality to spike protein (He et al. 2020; Shang et al. 2020). The in silico pharmacological assessment delights that these parts display great fondness of medication like and ADMET properties (Table 5) (Shang et al. 2020). Thus, we suggest that HIV protease, and anti-infection inhibitors calming are the conceivable lead drug atoms for spike protein and preclinical investigations needed to endorse the promising restorative capacity against COVID-19 (Agostini et al. 2020; Shajahan et al. 2020). This examination is proposing that these mixtures might be material in the organization of COVID-19 and ought to be investigated true to form leads in the medication advancement against SARS-CoV-2. Further in vitro and in vivo endorsement of these compounds is supported.

\section{Conclusions}

This examination features are to brief clarification of Emerging infectious diseases in current situation and EIDs would bring about enormous mortality and significant effects on social strength and financial advancement. EIDs have enhance a great common health problem worldwide, Factors adding to Arising irresistible sicknesses. Components adding to Emerging irresistible sicknesses, transmission of Infectious agents and explain about categories of Emerging infectious diseases (e.g., Influenza virus, HIV/AIDS \& Corona virus). Elaborate importance of Molecular docking is a computational tool on Emerging infectious diseases, virtual screening like distinguishing novel ligands with atomic docking gives an incredibly helpful strategy for drug assurance since particles can be starting to have raised restricting fondness to an exceptionally specific. Docking contemplates are regularly approved applies extra computational strategies, for example, atomic unique recreation. The most blessed applicants from computational preliminaries can be inspected in vitro or in vivo, and finally progress to clinical preliminaries. The major in this study about Molecular Docking approach to determine novel drug compounds against the EIDs. Like swine flu targeted protein glycoprotein against drug compounds such as Stilbenoids_19, Stilbenoids_23, Stemonine, Tuberospironine, Croomine, Zanamivir, Oseltamir. For HIV/AIDS targeted protein HIV-1 protease inhibition, the mixtures, for example, amprenavir (APV), ritonavir (RTV), indinavir (IDV), tipranavir (TPV), saquinavir (SQV), lopinavir (LPV), fosamprenavir (FOS-APV), nelfinavir (NFV), atazanavir (ATV) and darunavir. For Corona virus targeted protein is S2 (Spike protein) against the drug molecules such as Cobicistat, Darunavir, Lopinavir, Ritonavir, Baricitinib, Ruxolitinib, Thalidomide, Chloroquine, Hydroxychloroquine, Artemisinin, Mefloquine, Pyrimethamine. These novel anti-inflammatory, anti-viral and anti-microbial drugs were concluded about strong hydrogen binding affinity and predicted amino acid active sites by using of in-vitro studies, the selected anti-novel drug compounds are using further clinical trials like cytotoxicity to find out toxicity of drug compounds, for the future in- vivo clinical trials. For example, the docking output shows Zanamivir was perceive as the inhibitor having the most exhaustingly great associations with flu neuraminidase. Nelfinavir and Saquinavar are shows strong interaction against HIV-1 protease. Erythromycin and Spiramycin are shows favourable interaction against the spike protein, these compounds proceed forward with in vivo testing, the consequences of in vivo considers reassert the aftereffects of the in-silico tests. unmistakably computational strategies are capacity of growing new give proof and drugs to different scientists that this is a dependable and successful method in medication revelation.

\section{Declarations}

\section{Funding}

Page $13 / 24$ 
No Funding

\section{Compliance with ethical standards}

\section{Conflicts of interest}

Authors declare that there is no conflict of interest

\section{References}

Agostini ML, Andres EL, Sims AC, Graham RL, Sheahan TP, Lu X, et al. Coronavirus susceptibility to the antiviral remdesivir (gs-5734) is mediated by the viral polymerase and the proofreading exoribonuclease. mBio.

2018;9(2):e00221-18.

Ahmad T, Khan M, Haroon Musa TH, Nasir S, Hui J, Rodriguez-Morales AJ (2020) COVID-19: Zoonotic aspects. Travel Med Infect Dis 36: 101607

Anderson TK, Macken CA, Lewis NS, Scheuermann RH, Van Reeth K, Brown IH, Swenson SL, Simon G, Saito T,Berhane Y, Ciacci-Zanella J, Pereda A, Davis CT, Donis RO, Webby RJ, Vincent AL (2016) A Phylogeny-Based global nomenclature system and automated annotation tool for $\mathrm{H} 1$ hemagglutinin genes from swine influenza $A$ viruses. mSphere 1: e00275-16.

Asokan GV, Kasimanickam RK (2013) Emerging infectious diseases, antimicrobial resistance and millennium development goals: Resolving the challenges through one health. Cen Asian J Glob Health 2:76

Awaidy SA, Al Hashami H (2020) Zoonotic Diseases in Oman: Successes, Challenges, and Future Directions. Vector Borne Zoonot. Dis. 20(1): 1-9

Becerra JC, Bildstein LS, Gach JS (2016) Recent insights into the HIV/AIDS pandemic. Microb Cell 3:451-475

Bennett JE, Dolin R, Blaser MJ (2019) Mandell, Douglas, and Bennett's principles and practice of infectious diseases. 9th ed. Elsevier, Philadelphia; 3103-15

Bloom DE, Black S, Rappuoli R (2017) Emerging infectious diseases: A proactive approach, Proc Natl Acad Sci 114(16):4055-4059

Boni MF, Lemey P, Jiang X, Lam TT-Y, Perry B, Castoe T, Rambaut A, Robertson DL (2020) Evolutionary origins of the SARS-CoV-2 sarbecovirus lineage responsible for the COVID-19 pandemic. Nat. Microbiol 5:1408-1417

Cascella M, Rajnik M, Cuomo A, Dulebohn SC, Di Napoli R (2020) Features, Evaluation and Treatment Coronavirus (COVID-19); StatPearls [Internet], StatPearls Publishing, Treasure Island (FL).

https://www.ncbi.nlm.nih.gov/books/NBK554776/

Chen Y, Liu Q, Guo D (2020). Emerging coronaviruses: Genome structure, replication, and pathogenesis. Journal of Medical Virology 92(4): 418-423

Cheng LP, Wang TC, Yu R, Li M, Huang JW (2018) Design, synthesis and biological evaluation of novel zanamivir derivatives as potent neuraminidase inhibitors. Bioorganic \& medicinal chemistry letters, 28(23-24): 3622-3629,

Cimarelli A, Darlix JL (2014) HIV-1 reverse transcription. Methods MolBiol 1087:55-70

Page 14/ 24 
Cunningham AA, Daszak P, Wood JLN (2017) One Health, emerging infectious diseases and wildlife: two decades of progress? Phil. Trans R Soc B 372: 20160167

Dammalli M, Chandramohan V, Biradar MI, Nagaraju N, Gangadharappa BS (2014) In silico analysis and identification of novel inhibitor for new H1N1 swine influenza virus. Asian Pac J Trop Dis 4:S635-S640

Eisinger RW, Fauci AS (2018) Ending the HIV/AIDS Pandemic. Emerg Infect Dis 24(3): 413-416

Eisinger RW, Dieffenbach CW, Fauci AS (2019) HIV viral load and transmissibility of HIV infection: undetectable equals untransmittable. JAMA 321(5):451-452

Fauci AS, Redfield RR, Sigounas G, Weahkee MD, Giroir BP (2019) Ending the HIV epidemic: a plan for the United States. JAMA 321(9):844-5

Ferreira LG, Dos Santos RN, Oliva G, Andricopulo AD (2015) Molecular docking and structure-based drug design strategies Molecules, 20(7):13384-13421,

Gordon CJ, Tchesnokov EP, Woolner E, Perry JK, Feng JY, Porter DP, Götte M (2020) Remdesivir is a direct-acting antiviral that inhibits RNA-dependent RNA polymerase from severe acute respiratory syndrome coronavirus 2 with high potency. J Biol Chem https://doi.org/10.1074/jbc.RA120.013679

Grace D, Gilbert K, Lapar L, Unger F, Fèvre F, Nguyen-Viet H, and Schelling E, (2011) Zoonotic Emerging Infectious Disease in Selected Countries in Southeast Asia: Insights from Eco health. Ecohealth J 8:55-62

He F, Deng Y, Li W (2020) Coronavirus disease 2019: What we know? Journal of Medical Virology 92(7): 719-725,

Henritzi D, Hoffmann B, Wacheck S, Pesch S, Herrler G, Beer M, et al. (2019) A newly developed tetraplex real-time RTPCR for simultaneous screening of influenza virus types A, B, C and D. Influenza Other Respir Viruses 13:71-82.

Hung, K.K.C., Mark, C.K.M., Yeung, M.P.S. et al. (2018) The role of the hotel industry in the response to emerging epidemics: a case study of SARS in 2003 and H1N1 swine flu in 2009 in Hong Kong. Global Health 14: 117

Jacobson LE (2020) President's Emergency Plan for AIDS Relief (PEPFAR) Policy Process and the Conversation around HIV/AIDS in the United States. Journal of Development Policy and

Practice. https://doi.org/10.1177/2455133320952210

Jayakanthan M, Chandrasekar S, Muthukumaran J, Mathur P P (2010) Analysis of CYP3A4-HIV-1 protease drugs interactions by computational methods for Highly Active Antiretroviral Therapy in HIV/AIDS. Journal of Molecular Graphics and Modelling 28:455-463

Jin L, Lamster I, Greenspan J, Pitts N, Scully C, Warnakulasuriya S (2016) Global burden of oral diseases: Emerging concepts, management and interplay with systemic health. Oral Dis 22: 609-619

Kazhila CC (2019)Chemical diversity and activity profiles of HIV-1 reverse transcriptase inhibitors from plants. RevistaBrasileira de Farmacognosia 29:504-28

Kilian M, Chapple I, Hannig M, Marsh P, Meuric V, Pedersen A, Tonetti M, Wade W, Zaura, E (2016). he oral microbiomeAn update for oral healthcare professionals. Br Dent J 221:657-666 
Lai, Y., Yan, Y., Liao, S. Li Y, Ye Y, Liu N, Zhao F, Xu P (2020) 3D-quantitative structure-activity relationship and antiviral effects of curcumin derivatives as potent inhibitors of influenza H1N1 neuraminidase. Arch Pharm Re. 43: 489-502

Lewis NS, Russell CA, Langat P, Anderson TK, Berger K, Bielejec F, et al. (2016) ESNIP3 consortium. The global antigenic diversity of swine influenza A viruses. eLife 5: e12217.

Li JY, You Z, Wang Q, Zhou ZJ, Qiu Y, Luo R, Xing-Yi G (2020). The epidemic of 2019-novel-coronavirus (2019-nCoV) pneumonia and insights for emerging infectious diseases in the future. Microbes and Infection 22(2):80-85.

Liu SL, Saif L (2020) Emerging Viruses without Borders: The Wuhan Coronavirus. Viruses 12: 130

Marcus JL, Hurley LB, Nguyen DP, Silverberg MJ, Volk JE (2017) Redefining human immunodeficiency virus (HIV) preexposure prophylaxis failures. Clin Infect Dis 65(10):1768-9

Massinissa Si Mehand, Piers Millett, Farah Al-Shorbaji, Cathy Roth, Marie PauleKieny, Bernadette Murgue, World Health Organization Methodology to Prioritize Emerging Infectious Diseases, ww.cdc.gov/eid, Vol. 24, No. 9, September 2018.

Mehand MS, Al-Shorbaji F, Millett P, Murgue B (2018) The WHO R\&D Blueprint: 2018 review of emerging infectious diseases requiring urgent research and development efforts. Antivir Res 159:63-67

Mehand MS, Millett P, Al-Shorbaji F, et al. (2018) World Health Organization Methodology to Prioritize Emerging Infectious Diseases in Need of Research and Development. Emerg Infect Dis 24(9):e171427

Minardi da Cruz JC, Singh DK, Lamara A, Chebloune Y (2013) Small ruminant lentiviruses (SRLVs) break the species barrier to acquire new host range. Viruses 5:1867-84.

Monamele CG, Njifon HLM, Vernet M-A, Njankouo MR, Kenmoe S, Yahaya AA, et al. Molecular characterization of influenza A (H1N1) pdm09 in Cameroon during the 2014-2016 influenza seasons. PloS one. 14(1) e0210119.

Morens DM, Fauci AS (2020) Emerging pandemic diseases: how we got to COVID-19. Cell 182:1077-1092

Mugosa B, Vujosevic D, Ciccozzi M, Valli MB, Capobianchi MR, Lo Presti A, et al. (2016) Genetic diversity of the haemagglutinin $(\mathrm{HA})$ of human influenza a $(\mathrm{H} 1 \mathrm{~N} 1)$ virus in montenegro: Focus on its origin and evolution. Journal of medical virology. 88(11):1905-13. pmid:27088433

Nasr N, Alshehri AA, Wright TK, Shahid M, Heiner BM, Harman AN, Botting RA, Helbig KJ, Beard MR, Suzuki K et al. (2017) Mechanism of Interferon-Stimulated Gene Induction in HIV-1-Infected Macrophages. J Virol 91: e00744-17

Nii-Trebi NI (2017) Emerging and neglected infectious diseases: insights, advances, and challenges. BioMed Res Int 2017:5245021.

Pagadala NS, Syed K, Tuszynski J (2017) Software for Molecular docking: A review. Biophysical Reviews 9(2):91-102, Phillips MA, Stewart MA, Woodling DL, Xie ZR (2014) Has Molecular Docking Ever Brought us a Medicine? In Molecular Docking. IntechOpen Limited p. 141, London, UK

Poorolajal J (2020) Geographical Distribution of COVID-19 Cases and Deaths Worldwide. J Res Health Sci 20(3): e00483

Pornillos O, Garrus JE, Sundquist WI (2020) Mechanisms of enveloped RNA virus budding. Trends Cell Biol 12: 569579

Page $16 / 24$ 
Prashantha C, Gouthami K, Lavanya L, Bhavanam S, Jain A, Shakthiraju R, Suraj V, Sahana K, Sujana H, Guruprasad N (2021) Molecular screening of antimalarial, antiviral, anti-inflammatory and HIV protease inhibitors against spike glycoprotein of Coronavirus. Journal of Molecular Graphics \& Modelling 102: 107769

Rueda S, Mitra S, Chen S, Gogolishvili D, Globerman J, Chambers L, et al. (2016) Examining the associations between HIV-related stigma and health outcomes in people living with HIV/AIDS: a series of meta-analyses. BMJ Open 6(7):e011453.

Sarafis P, Stavrakakis P, chalaris M, stamataki P, Zyga S, Saroglou G (2010), Emerging infectious diseases, Journal of Environmental Protection and Ecology 11: 917-929.

\section{Schoeman D, Fielding BC (2019) Coronavirus envelope protein: current knowledge. Virol J 16: 69}

Shajahan A, Heiss C, Ishihara M, Azadi P. Glycomic and glycoproteomic analysis of glycoproteins-a tutorial. Anal Bioanal Chem. 409:4483-4505, 2017.

Shang J, Ye G, Shi K, Wan Y, Luo C, Aihara H, Geng Q, Auerbach A, Li F (2020) Structural basis of receptor recognition by SARS-CoV-2. Nature 581:221-224

Sk MF, Roy R, Kar P (2020) Exploring the potency of currently used drugs against HIV-1 protease of subtype D variant by using multiscale simulations. J. Biomol. Struct. Dyn

Smitha KM., Machalaba CC, Seifmanc R, Feferholtza Y, Karesha WB (2019).Infectious disease and economics: The case for considering multi-sectoral impacts, One Health 7:100080

Sohrabi C, Alsafi Z, O’Neill N, Khan M, Kerwan A, Al-Jabir A, losifidis C, Agha R (2020) World Health Organization declares global emergency: A review of the 2019 novel coronavirus (COVID-19). International Journal of Surgery 76 : 71-76.

Taiaroa G, Rawlinson D, Featherstone L, Pitt M, Caly L, Druce J, Purcell D, Harty L, Tran T, Roberts J, Catton M, Williamson D, Coin L, Duchene S (2020) Direct RNA sequencing and early evolution of SARS-CoV-2. BioRxiv

Tang L, Bie B, Park S-E, Zhi D (2018) Social media and outbreaks of emerging infectious diseases: a systematic review of literature. Am J Infect Control 46: 962-972

Tarasova O, Poroikov V, Veselovsky, A (2018) Molecular Docking Studies of HIV-1 Resistance to Reverse Transcriptase Inhibitors: Mini-Review. Molecules,23(5). doi: 10.3390/molecules 23:1233

Townsend AK, Hawley DM, Stephenson JF, Williams KEG (2020) Emerging infectious disease and the challenges of social distancing in human and non-human animals, Proc R Soc B 287: 20201039

Valdiserri RO, Holtgrave DR (2019) Ending HIV in America: not without the power of community. AIDS Behav 23(11):2899-903

van Doorn HR (2014), Emerging infectious diseases, Medicine 42(1): 60-63

Velavan T P, Meyer CG (2020) The COVID-19 epidemic. Tropical Medicine \& International Health 25(3): 278-280

Venkatramanan S, Lewis B, Chen J, Higdon D, Vullikanti A, Marathe M (2018) Using data-driven agent-based models for forecasting emerging infectious diseases. Epidemics 22:43-49

Page $17 / 24$ 
Viegi G, Maio S, Fasola S, Baldacci S (2020) Global burden of chronic respiratory diseases. J Aerosol Med Pulm Drug Deliv 33(4):171-177.

Wang M, Cao R, Zhang L, Yang X, Liu J, Xu M, et al. (2020) Remdesivir and chloroquine effectively inhibit the recently emerged novel coronavirus (2019-nCoV) in vitro. Cell Res 30: 269-271

World Health Organization (2012) Developing Tools for Strategic Communication to the Media on Emerging Infectious Diseases (EIDs).Available online: http://apps.searo.who.int/PDS_DOCS/B4803.pdf

World Health Organization (WHO) (2020) WHO Statement Regarding Cluster of Pneumonia Cases in Wuhan, WHO, China. Beijing

World health statistics (2019) monitoring health for the SDGs, sustainable development goals. Geneva: World Health Organization. Licence: CC BY-NC-SA 3.0 IGO

Xie Q, He X, Yang F, Liu X, Li Y, Liu Y, Yang Z, Yu J, Zhang B, Zhao W (2018) Analysis of the Genome Sequence and Prediction of B-Cell Epitopes of the Envelope Protein of Middle East Respiratory Syndrome-Coronavirus. IEEE/ACM Trans. Comput. Biol. Bioinform 15:1344-1350

Yang Y, Du L, Liu C, Wang L, Ma C, Tang J, et al. (2014) Receptor usage and cell entry of bat coronavirus HKU4 provide insight into bat-to-human transmission of MERS coronavirus. Proc Natl Acad Sci U S A.111(34):12516-21.

Yasuhara A, Yamayoshi S, Soni P, Takenaga T, Kawakami C, Takashita E, et al. (2017) Diversity of antigenic mutants of influenza A (H1N1) pdm09 virus escaped from human monoclonal antibodies. Scientific Reports 7(1):17735.

pmid:29255273

Zhan P, Pannecouque C, De Clercq E, Liu X (2016) Anti-HIV drug discovery and development: current innovations and future trends. J Med Chem 59:2849-78

Zhu M, Dong B, Zhang GN, Wang JX, Cen S, Wang YC (2019) Synthesis and biological evaluation of new HIV-1 protease inhibitors with purine bases as P2-ligands. Bioorg Med Chem Lett. 29(12): 1541-1545

Zhu N, Zhang D, Wang W, Li X, Yang B, Song J, et al. (2020) A novel coronavirus from patients with pneumonia in China, 2019. N Engl J Med 382:727-33

\section{Tables}

Table 1. Various emerging pathogens have been shown their impact on human beings in different period of times. 


\begin{tabular}{|c|c|c|c|c|}
\hline Microorganism & Disease & Year & Mechanism of action & Reference \\
\hline Rotavirus & $\begin{array}{l}\text { Infantile } \\
\text { gastroenteritis }\end{array}$ & 1973 & $\begin{array}{l}\text { Rotavirus primarily infects enterocytes } \\
\text { and induces diarrhoea through the } \\
\text { destruction of absorptive enterocytes. }\end{array}$ & $\begin{array}{l}\text { Grace et al. } \\
2011\end{array}$ \\
\hline $\begin{array}{l}\text { Legionella } \\
\text { pneumophila }\end{array}$ & $\begin{array}{l}\text { Legionnaires } \\
\text { disease }\end{array}$ & 1977 & $\begin{array}{l}\text { Biogenesis of the Legionella-containing vacuole } \\
\text { (LCV). phagocytosis through PI-3-kinase- } \\
\text { dependent and/or -independent mechanisms, } \\
\text { within minutes, the nascent LCV avoids } \\
\text { interactions with endosomes, fuses transiently } \\
\text { with mitochondria, and intercepts ER exit vesicles } \\
\text { bearing COP II markers. }\end{array}$ & $\begin{array}{l}\text { Grace et al. } \\
2011\end{array}$ \\
\hline Ebola virus & $\begin{array}{l}\text { Ebola } \\
\text { haemorrhagic } \\
\text { fever }\end{array}$ & 1977 & $\begin{array}{l}\text { Ebola virus activates the formation of } \\
\text { macropinosomes via intracellular signals } \\
\text { including the role of HAVCR1 (TM1), } \\
\text { which recently has demonstrated the } \\
\text { roles of the TIM-1 as a receptor or a } \\
\text { cofactor for entry of Ebola virus. }\end{array}$ & $\begin{array}{l}\text { Mehand } \text { et } \\
\text { al. 2018 }\end{array}$ \\
\hline $\begin{array}{l}\text { Borrelia } \\
\text { burgdorferi }\end{array}$ & Lyme disease & 1982 & $\begin{array}{l}\text { After the pathogen is transmitted, it will } \\
\text { acclimate to the mammalian conditions. } \\
\text { Borrelia burgdorferi will change } \\
\text { its glycoproteins and proteases on its } \\
\text { plasma membrane to facilitate its } \\
\text { dissemination throughout the blood. In } \\
\text { response, the host will initiate } \\
\text { an inflammatory response to attempt to } \\
\text { remove the infection. }\end{array}$ & $\begin{array}{l}\text { Mehand et } \\
\text { al. 2018 }\end{array}$ \\
\hline HIV & AIDS & 1983 & $\begin{array}{l}\text { Entry to the cell begins through } \\
\text { interaction of the trimeric envelope } \\
\text { complex (gp160 spike) on the HIV viral } \\
\text { envelope and both CD4 and a chemokine } \\
\text { co-receptor } \\
\text { either CCR5 or CXCR4, but others are } \\
\text { known to interact) on the target cell } \\
\text { surface. }\end{array}$ & $\begin{array}{l}\text { Mehand et } \\
\text { al. 2018 }\end{array}$ \\
\hline $\begin{array}{ll}\text { Hepatitis } & \mathrm{C} \\
\text { virus } & \end{array}$ & Hepatitis & 1989 & $\begin{array}{l}\text { Both virus and host cell components } \\
\text { involved in virus entry may serve as } \\
\text { targets for the development of HCV entry } \\
\text { inhibitors. Viral entry may be inhibited by } \\
\text { blocking interaction between the virus } \\
\text { and the target cell, by interfering with } \\
\text { post binding events, and by interfering } \\
\text { with viral fusion. }\end{array}$ & $\begin{array}{l}\text { Mehand et } \\
\text { al. } \\
\text { 2018; World } \\
\text { Health } \\
\text { Organization } \\
\text { (2012) }\end{array}$ \\
\hline $\begin{array}{l}\text { Vibrio cholerae } \\
0139\end{array}$ & Cholerae & 1992 & $\begin{array}{l}\text { Cholera toxin binds to the ganglioside } \\
\text { receptor on the host epithelial cells, } \\
\text { triggers endocytosis of the holotoxin. The } \\
\text { internalized CT moves from the } \\
\text { endosomes to the Golgi complex and } \\
\text { endoplasmic reticulum (ER). }\end{array}$ & $\begin{array}{l}\text { Mehand et } \\
\text { al. } \\
\text { 2018; World } \\
\text { Health } \\
\text { Organization } \\
\text { (2012) }\end{array}$ \\
\hline $\begin{array}{ll}\text { Influenza } & \text { virus } \\
\text { A H5N1 } & \end{array}$ & Influenza & 1997 & $\begin{array}{l}\text { The avian influenza hemagglutinin binds } \\
\text { alpha 2-3 sialic acid receptors, while } \\
\text { human influenza hemagglutinins bind } \\
\text { alpha } 2-6 \text { sialic acid receptors. This } \\
\text { means when the H5N1 strain infects } \\
\text { humans, it will replicate in the lower } \\
\text { respiratory tract, and consequently will } \\
\text { cause viral pneumonia. }\end{array}$ & $\begin{array}{l}\text { World } \\
\text { Health } \\
\text { Organization } \\
(2012)\end{array}$ \\
\hline $\begin{array}{l}\text { SARS } \\
\text { coronavirus }\end{array}$ & $\begin{array}{l}\text { Severe acute } \\
\text { respiratory } \\
\text { syndrome }\end{array}$ & 2002 & $\begin{array}{l}\text { Severe acute respiratory syndrome } \\
\text { (SARS)-infected cells are crucial toward } \\
\text { understanding the pathogenesis. } \\
\text { Angiotensis- converting enzyme 2, and } \\
\text { also a binding receptor, liver/lymph } \\
\text { node-specific ICAM-3-grabbing non- } \\
\text { integrin (CD209L). }\end{array}$ & $\begin{array}{l}\text { World } \\
\text { Health } \\
\text { Organization } \\
(2012)\end{array}$ \\
\hline
\end{tabular}




\begin{tabular}{|l|l|l|l|} 
Corona virus & Covid-19 & $\begin{array}{l}\text { The spike proteins covering the corona } \\
\text { virus bind ACE2 receptors primarily on } \\
\text { type II alveolar cells, allowing the virus } \\
\text { to inject its RNA. The RNA hijacks the } \\
\text { cell, telling it to assemble many more } \\
\text { copies of the virus and release them into } \\
\text { the alveolus. }\end{array}$ & $\begin{array}{l}(2012) \\
\text { the }\end{array}$ \\
\hline
\end{tabular}

Table 2. The annual cause specific mortality

\begin{tabular}{|c|c|c|}
\hline Infections & $\begin{array}{l}\text { Worldwide } \text { Deaths } \\
\text { occur }\end{array}$ & References \\
\hline $\begin{array}{l}\text { chronic obstructive } \\
\text { pulmonary disease }\end{array}$ & 3.2 million & Viegi et al. 2020 \\
\hline Diarrheal diseases & 2.5 million deaths & World health statistics (2019) \\
\hline HIV/AIDS & 1.8 million deaths & $\begin{array}{l}\text { Mehand et al. 2018; } \text { World Health } \\
\text { Organization (2019) }\end{array}$ \\
\hline Tuberculosis & 1.3 million deaths & $\begin{array}{l}\text { Mehand et al. 2018; World Health } \\
\text { Organization (2019) }\end{array}$ \\
\hline Malaria & 0.8 million deaths & World health statistics (2019) \\
\hline Meningitis & 0.3 million deaths & $\begin{array}{l}\text { Mehand et al. 2018; World Health } \\
\text { Organization (2019) }\end{array}$ \\
\hline Pertussis & 0.2 million deaths & Mehand et al. 2018 \\
\hline Measles & 0.2 million deaths & $\begin{array}{l}\text { Mehand et al. 2018; World Health } \\
\text { Organization (2019) }\end{array}$ \\
\hline Hepatitis B & 0.1 million deaths & World Health Organization (2012) \\
\hline Covid -19 & $\begin{array}{l}1.17 \text { million deaths till } \\
\text { Nov2020 }\end{array}$ & Poorolajal 2020 \\
\hline Other infectious diseases & 1.2 million deaths & World health statistics (2019) \\
\hline
\end{tabular}

Table 3. The binding modes of HIV-1 protease drugs into CYP3A4 isoenzyme 


\begin{tabular}{|c|c|c|c|c|c|c|}
\hline rugs & H-bond donor & $\begin{array}{l}\text { H-bond } \\
\text { accepter }\end{array}$ & $\begin{array}{l}\text { H- } \\
\text { bond } \\
\text { length } \\
\left(A^{\circ}\right)\end{array}$ & $\begin{array}{l}\Delta \mathrm{G} \\
(\mathrm{kcal} / \mathrm{mol})\end{array}$ & $\begin{array}{l}\text { Docking } \\
\text { energy } \\
\text { (kcal/mol) }\end{array}$ & References \\
\hline itonavir & $\begin{array}{l}\text { CYP:A:ARG212:HH22 } \\
\text { CYP:A:GLU374:HN }\end{array}$ & $\begin{array}{l}\text { DRUG: } \\
\text { :O } \\
\text { DRUG:N }\end{array}$ & $\begin{array}{l}1.767 \\
1.956\end{array}$ & -7.74 & 15.31 & Zhu et al. 2019 \\
\hline mprenavir & CYP:A:ARG212:HH22 & DRUG::O & 1.723 & -6.18 & 10.96 & Sk et al. 2020 \\
\hline ipranavir & CYP:A:ARG105:HE & DRUG::O & 1.829 & -10.07 & 10.96 & $\begin{array}{l}\text { Tarasova et al. } \\
2018 .\end{array}$ \\
\hline Idinavir & $\begin{array}{l}\text { CYP:A:ARG212:HE } \\
\text { CYP:A:ARG212:HH22 }\end{array}$ & $\begin{array}{l}\text { DRUG::O } \\
\text { DRUG::O }\end{array}$ & $\begin{array}{l}2.14 \\
1.877\end{array}$ & -3.92 & 8.76 & $\begin{array}{l}\text { Cheng et al. } \\
2018\end{array}$ \\
\hline aquinavir & CYP:A:ARG212:HH22 & DRUG::N & 1.882 & -6.29 & 11.26 & Sk et al. 2020 \\
\hline 「elfinavir & $\begin{array}{l}\text { CYP:A:HEM508:NA } \\
\text { CYP:A:ARG372:O }\end{array}$ & $\begin{array}{l}\text { DRUG::H } \\
\text { DRUG::H }\end{array}$ & $\begin{array}{l}1.993 \\
1.92\end{array}$ & -10.06 & 13.89 & Zhu et al. 2019 \\
\hline opinavir & CYP:A:ARG106:HN & DRUG::O & 1.906 & -12.42 & 17.43 & $\begin{array}{l}\text { Cheng et al. } \\
2018\end{array}$ \\
\hline osamprenavir & CYP:A:GLU374:OE1 & DRUG::H & 2.075 & -8.55 & 16.89 & Zhu et al. 2019 \\
\hline arunavir & CYP:A:ARG212:HH22 & DRUG::O & 1.794 & -8.97 & 13.69 & \\
\hline tazanavir & $\begin{array}{l}\text { CYP:A:SER119:HG } \\
\text { CYP:A:ALA370:O }\end{array}$ & $\begin{array}{l}\text { DRUG::H } \\
\text { DRUG::O }\end{array}$ & $\begin{array}{l}1.99 \\
2.037\end{array}$ & -7.40 & 13.08 & $\begin{array}{l}\text { Cheng et al. } \\
2018\end{array}$ \\
\hline
\end{tabular}

Table 4. Docking results of modelled protein N1 with antiviral compounds 


\begin{tabular}{|c|c|c|c|c|c|c|}
\hline \begin{tabular}{|l} 
Drugs \\
\end{tabular} & $\begin{array}{r}\mathrm{H}- \\
\text { bond }\end{array}$ & $\begin{array}{l}\text { H-bond } \\
\text { accepter }\end{array}$ & $\begin{array}{l}\text { H-bond } \\
\text { length }\left(A^{\circ}\right)\end{array}$ & $\begin{array}{l}\text { Ligand } \\
\text { atom }\end{array}$ & $\begin{array}{l}\text { Lead- } \\
\text { IT } \\
\text { Score }\end{array}$ & References \\
\hline \begin{tabular}{|l|} 
Stilbenoids_19 \\
\end{tabular} & 6 & $\begin{array}{l}\text { THR131, } \\
\text { PHE133, } \\
\text { PHE133, } \\
\text { CYS161, } \\
\text { THR131, } \\
\text { CYS161. }\end{array}$ & $\begin{array}{l}0.220741,0.236 \\
485,0.185986, \\
0.231471,0.189 \\
968 .\end{array}$ & $\begin{array}{l}\text { 02, 04, O2, } \\
\text { H15, H16, } \\
\text { H16. }\end{array}$ & -14.018 & $\begin{array}{l}\text { Dammalli et } \\
\text { al. } 2014\end{array}$ \\
\hline \begin{tabular}{|l|} 
Stilbenoids_23 \\
\end{tabular} & 5 & $\begin{array}{l}\text { THR131, } \\
\text { ILE163, } \\
\text { ILE163, } \\
\text { ILE163, } \\
\text { GLU165. }\end{array}$ & $\begin{array}{|lcc|}0.201 & 911, & 0.204 \\
388, & & 0.189 \\
694, & 0.211 & 992, \\
0.177 & 781 . & \\
\end{array}$ & $\begin{array}{ll}\text { O4, } & \text { O3, } \\
\text { O5, } & \text { O2, } \\
\text { O5. } & \end{array}$ & $\begin{array}{l}-9.065 \\
9\end{array}$ & $\begin{array}{l}\text { Lai et } \\
\text { al. } 2020\end{array}$ \\
\hline Stemonine & 4 & $\begin{array}{l}\text { ILE117, } \\
\text { GLY440, } \\
\text { SER105, } \\
\text { SER105. }\end{array}$ & $\begin{array}{|lrr|}0.193 & 543, & 0.198 \\
523, & 0.191 & 605, \\
0.161 & 684 . & \\
\end{array}$ & $\begin{array}{l}\text { O3, O4, } \\
\text { H15, H16, }\end{array}$ & $\begin{array}{l}-7.831 \\
2\end{array}$ & $\begin{array}{l}\text { Yasuhara et } \\
\text { al. } 2017\end{array}$ \\
\hline \begin{tabular}{|l|} 
Tuberospironine \\
\end{tabular} & 6 & $\begin{array}{l}\text { THR131, } \\
\text { ILE163, } \\
\text { ILE163, } \\
\text { GLU165, } \\
\text { ILE163, }\end{array}$ & $\begin{array}{l}0.211429,0.172 \\
223,0.195641 \\
0.183567,0.196 \\
434,0.152373 .\end{array}$ & $\begin{array}{l}\text { 07, O25, } \\
\text { O3, O25, } \\
\text { H51, H51. }\end{array}$ & $\begin{array}{l}-7.553 \\
2\end{array}$ & $\begin{array}{l}\text { Dammalli et } \\
\text { al. } 2014\end{array}$ \\
\hline \begin{tabular}{|l} 
Croomine \\
\end{tabular} & 3 & $\begin{array}{l}\text { GLU425, } \\
\text { GLU425, } \\
\text { GLU425. }\end{array}$ & $\begin{array}{l}0.286333,0.154 \\
825,0.212776 .\end{array}$ & $\begin{array}{l}\mathrm{O} 1, \mathrm{O} 2, \\
\mathrm{H} 51 .\end{array}$ & -7.365 & $\begin{array}{l}\text { Lai et } \\
\text { al. } 2020\end{array}$ \\
\hline Zanamivir & 6 & $\begin{array}{l}\text { SER105, } \\
\text { ILE117, } \\
\text { GLY440, } \\
\text { ILE117 } \\
\text { GLY440, } \\
\text { ILE117, } \\
\text { SER105, } \\
\text { SER105, } \\
\text { SER105. }\end{array}$ & $\begin{array}{l}0.231101,0.237 \\
100,0.199 \\
522,0.164 \\
569,0.222 \\
359,0.207 \\
947,0.187 \\
988,0.200653 .\end{array}$ & $\begin{array}{l}\text { N11, O2, } \\
\text { O2, H35, } \\
\text { H35, H36, } \\
\text { H41, H42, } \\
\text { H43. }\end{array}$ & $\begin{array}{l}-3.654 \\
6\end{array}$ & $\begin{array}{l}\text { Yasuhara et } \\
\text { al. } 2017\end{array}$ \\
\hline Oseltamvir & 5 & $\begin{array}{l}\text { PRO120, } \\
\text { PRO120, } \\
\text { GLU425, } \\
\text { PRO120, } \\
\text { GLU425. }\end{array}$ & $\begin{array}{l}0.305438,0.290 \\
713,0.188 \\
715,0.235302 .\end{array}$ & $\begin{array}{l}\text { O4, O4, } \\
\text { O3, H50, } \\
\text { H51, }\end{array}$ & $\begin{array}{l}-3.597 \\
2\end{array}$ & $\begin{array}{l}\text { Dammalli et } \\
\text { al. } 2014\end{array}$ \\
\hline
\end{tabular}

Table 5. Docking results of modelled spike protein S2 with antiviral, antimicrobial and antiinflammatory compound. 


\begin{tabular}{|c|c|c|c|c|c|}
\hline Drugs & $\begin{array}{c}\mathrm{H}- \\
\text { bond }\end{array}$ & $\begin{array}{l}\text { Binding } \\
\text { Energy }\end{array}$ & Amino acids & KI & References \\
\hline Cobicistat & 6 & 8.3 & $\begin{array}{l}\text { Phe464, Pro426, Pro463, } \\
\text { Leu461 }\end{array}$ & $17.40 \mu \mathrm{M}$ & $\begin{array}{l}\text { Agostini et al. } \\
2018\end{array}$ \\
\hline Darunavir & 5 & 7.4 & Phe464, Arg355, Leu517 & $\begin{array}{l}603.1 \\
\mu \mathrm{M}\end{array}$ & He et al. 2020 \\
\hline Lopinavir & 5 & 9.1 & $\begin{array}{l}\text { Phe515, Phe426, Asp427, } \\
\text { Lys424, } \\
\text { Phe429 Gly496, Tyr453, } \\
\text { Ile418, Leu455. }\end{array}$ & $\begin{array}{l}39.22 \\
\mu \mathrm{M}\end{array}$ & $\begin{array}{l}\text { Velavan et al. } \\
2020\end{array}$ \\
\hline Ritonavir & 4 & 8.0 & $\begin{array}{l}\text { Phe464, Pro426, Pro463, } \\
\text { Leu461 }\end{array}$ & \begin{tabular}{|l|}
30.44 \\
$\mu \mathrm{M}$
\end{tabular} & $\begin{array}{l}\text { Velavan et al. } \\
2020\end{array}$ \\
\hline Baricitinib & 6 & 5.8 & $\begin{array}{l}\text { Pro426, Ser514, Arg355, } \\
\text { Phe464, Asp428. }\end{array}$ & $\begin{array}{l}17.40 \\
\mu \mathrm{M}\end{array}$ & He et al. 2020 \\
\hline Ruxolitinib & 4 & 6.5 & Asp428, Ser514, Arg355 & $1.21 \mu \mathrm{M}$ & He et al. 2020 \\
\hline Thalidomide & 3 & 6.5 & Asn487, Tyr473, Arg457 & $\begin{array}{l}99.85 \\
\mathrm{uM}\end{array}$ & $\begin{array}{l}\text { Prashantha et } \\
\text { al. } 2021\end{array}$ \\
\hline Chloroquine & 2 & 6.2 & Lys462, Ser469 & $7.46 \mathrm{mM}$ & $\begin{array}{l}\text { Wang et al. } \\
2020\end{array}$ \\
\hline Hydroxychloroquine & 2 & 5.2 & Tyr453, Leu455 & $7.53 \mathrm{mM}$ & $\begin{array}{l}\text { Velavan et al. } \\
2020\end{array}$ \\
\hline Artemisinin & 2 & 6.86 .7 & Asn460, Lys462 & $\begin{array}{l}15.37 \\
\mu \mathrm{M}\end{array}$ & $\begin{array}{lll}\text { Wang } & \text { et } & \text { al. } \\
2020 & & \end{array}$ \\
\hline Mefloquine & 1 & 5.8 & Lys462 & $\begin{array}{l}835.56 \\
\mu M\end{array}$ & $\begin{array}{l}\text { Velavan et al. } \\
2020\end{array}$ \\
\hline Pyrimethamine & 1 & 6.2 & Lys462 & $\begin{array}{l}93.59 \\
\mu \mathrm{M}\end{array}$ & $\begin{array}{l}\text { Velavan et al. } \\
2020\end{array}$ \\
\hline
\end{tabular}

\section{Figures}

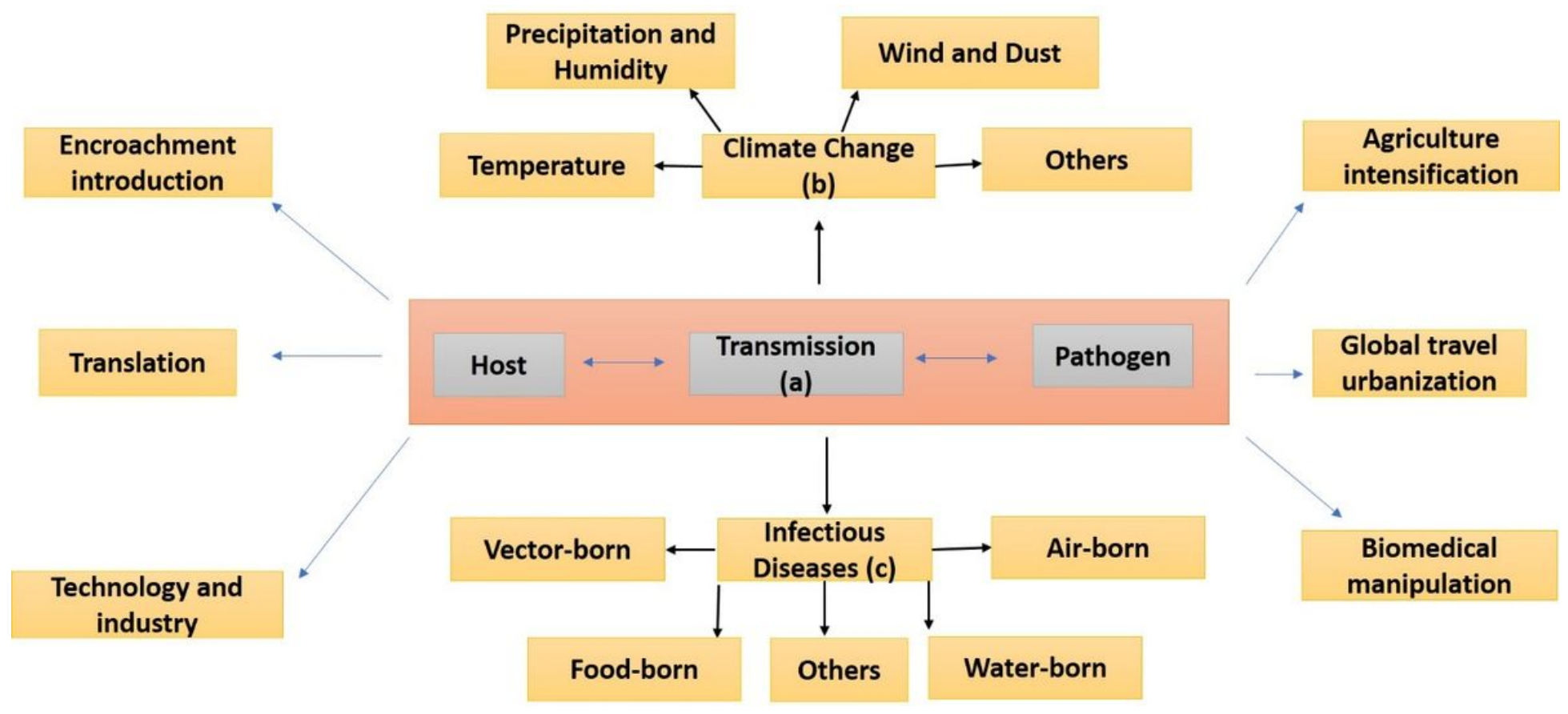

Figure 1

Factors influenced by emerging infectious diseases a. Microbial transformation and change: Microbial development, reaction to determination in climate. Breakdown in general wellbeing measures: Curtailment or decrease in avoidance programs, deficient disinfection and vector control measures. b. Ecological changes: farming, dams, changes in water 
biological systems, deforestation/reforestation, flood/dry season, starvation and environment changes. c. Human demographics, behaviour social occasions, Population development and relocation.

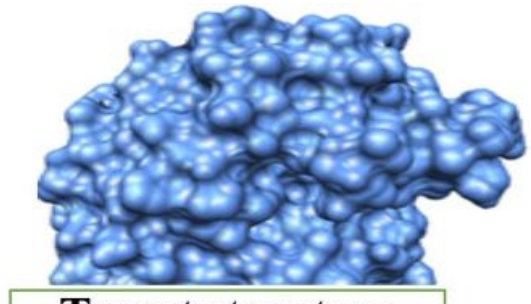

Target structure

PDB (a)
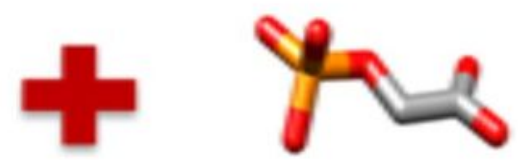

Ligand structure

PDB (b)

\section{Molecular docking structure-based virtual screening}

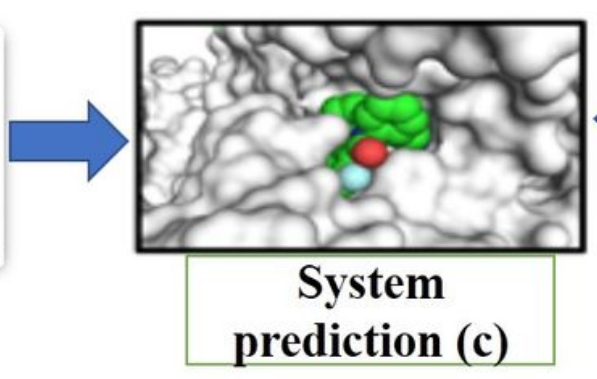

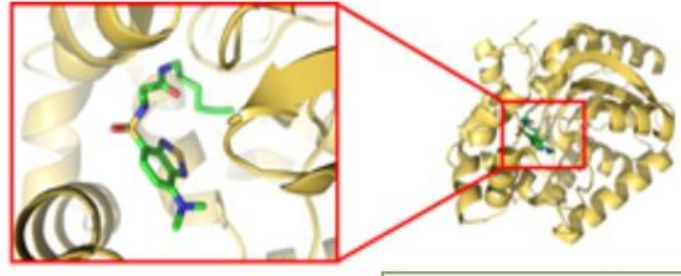

Docking score (e)

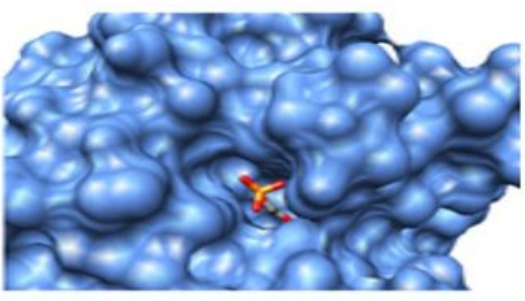

Binding site detection (d)

Figure 2

Schematic representation of Molecular dock screening of Protein-Ligand a. Homology modelling of protein structure, building a nuclear goal model of the target protein from its amino corrosive grouping and a trial three dimensional of related homologous protein. Protein structure should be in pdb file format. b. Three-dimensional (3D) coordinates were generated for all ligands with LigPrep, ligand selection has done based on the Pharmacophore properties of selected compounds based on Lipinski Rule of 5 and Veber's Rule. Ligands has converted pdb file format by using hyper chem. c. System prediction by ADMET and pass prediction. d. Binding detection by molecular docking (auto dock) completion of grid file and hydrogen binding network. e. Molecular docking uses scoring capacities to give a quick and crude estimation of the binding affinity. There are three essential kinds of scoring limits: power field based, data based genuine limits, and careful scoring capacities. 